\title{
Growth and production of cowpea cultivated with liming and nitrogen fertilization in the Eastern Amazon ${ }^{1}$
}

\author{
Milton Garcia Costa ${ }^{2 * \mathbb{D}}$, Eric Victor de Oliveira Ferreira ${ }^{2}$, Thiago Caio Moura Oliveira ${ }^{2}$, \\ Gutierre Pereira Maciel $l^{3}$, Francisco José Sosa Duque ${ }^{2}$, Wanderson Cunha Pereira ${ }^{2}$
}

$10.1590 / 0034-737 X 202168050011$

\begin{abstract}
In the northeastern of Pará, cowpea is one of the main protein sources of the population. This study aimed to evaluate the effects of liming, the $\mathrm{P}$ and $\mathrm{K}$ mineral fertilization, and the combination of seed inoculation with Rhizobium associated with mineral $\mathrm{N}$ supplementation in the growth and production of cowpea cultivars. Two experiments were carried out in two consecutive years at the Federal Rural University of Amazonia (Capitão Poço-PA). A randomized block experimental design with subdivided plots was used with four replications, two cowpea cultivars (BRS Tapaihum and BRS Marataoã) and six fertilization and liming treatments: i) without fertilization and without liming; ii) P and K mineral fertilization, liming and seed inoculation with Rhizobium; iii) $\mathrm{P}$ and $\mathrm{K}$ mineral fertilization and seed inoculation with Rhizobium; iv) N, P and K mineral fertilization and liming; v) P and K mineral fertilization and liming; and vi) N, P and $\mathrm{K}$ mineral fertilization, liming and seed inoculation with Rhizobium. Cowpea responded to liming and $\mathrm{P}$ and $\mathrm{K}$ mineral fertilization, but not $\mathrm{N}$ fertilization. There was no difference between the supply of $\mathrm{N}$ through seed inoculation or mineral fertilization. Thus, it is suggested to inoculate seeds with Rhizobium in order to maintain the soil $\mathrm{N}$ reserve.
\end{abstract}

Keywords: acidity correction; biological nitrogen fixation; Rhizobium; leguminous crops; amazon soils.

\section{INTRODUCTION}

Cowpea [Vigna unguiculata (L.) walp.] (Fabaceae) is a legume consumed as a high quality plant protein source worldwide, especially in Brazil, in which it is important for economy and food security, especially for small farmers in northeastern Pará (Silva et al., 2012). Despite its socioeconomic importance, productivity of cowpea is still low in Brazil, with an average of $476 \mathrm{~kg} \mathrm{ha}^{-1}$ (CONAB, 2020).

Biological nitrogen fixation (BNF) is a technology capable of increasing cowpea productivity (Gualter et al., 2011). The association of cowpea cultivation with $\mathrm{N}$-fixing bacteria guarantees the supply of $\mathrm{N}$, reducing production costs due to the lower use of N-mineral fertilizers (Soares et al., 2014; Chakirwa et al., 2019). The practice of inoculating seeds with rhizobacteria causes increases in the population of rhizobia as well as the efficiency of BNF (Gualter et al., 2011). On the other hand, BNF might be compromised in conditions of low technological input, mainly due to the lack of correction of soil acidity, fertilization, irrigation and adequate crop management (Melo \& Zilli, 2009). Attributes related to soil such as $\mathrm{pH}$, $\mathrm{Al}^{3+}$ and nutritional deficiency are capable of altering the symbiotic efficiency and development of beans (Soares et al., 2014; Farias et al., 2016).

Weathered soils are characteristic of tropical regions and present chemical restrictions to agriculture, especially considering Fabaceae plants, through soil acidity, which decreases the efficiency of BNF (Farias et al., 2016). Thus, soil acidity correction in the cultivation of cowpea is essential not only regarding the efficiency of BNF but also related to higher crop yields (Farias et al., 2016).

Submitted on August $18^{\text {th }}, 2020$ and accepted on February $07^{\text {th }}, 2021$.

${ }^{1}$ This work is part of the scientific initiation project (Pibic-CNPq) of the first author.

${ }^{2}$ Universidade Federal Rural da Amazônia, Campus Capitão Poço, Pará, Brazil, miltongarciacosta.2010@gmail.com; ericsolos@yahoo.com.br; thiagocaio1998@gmail.com; fransodu73@hotmail.com; wandersoncp@yahoo.com.br.

${ }^{3}$ Universidade Federal Rural da Amazônia, Instituto de Ciências Agrárias, Belém, Pará, Brazil. gutierre_maciel@hotmail.com.

*Corresponding author: miltongarciacosta.2010@gmail.com 
The combination of seed inoculation with rhizobia and the application of mineral $\mathrm{N}$ is a strategy commonly used in the cultivation of beans (Phaseolus vulgaris L.) (Brito et al., 2015). However, for the success of the combination of biological and mineral fertilization, it is important to know the dose of mineral $\mathrm{N}$ capable to meet the nutritional demands of the plant so there is not a reduction or inhibition of NBF (Brito et al., 2011).

This study aimed to evaluate the effects soil acidity correction, the $\mathrm{P}$ and $\mathrm{K}$ mineral fertilization, and the combination of seed inoculation with rhizobia associated with supplementation of mineral $\mathrm{N}$ on the growth and production of two cowpea cultivars.

\section{MATERIALAND METHODS}

The study was carried out at the Campus of the Federal Rural University of the Amazon (UFRA-CCP) (01'44'47' S and 47 03'34' W), in Capitão Poço, state of Pará, Brazil, in two consecutive years (July to October of 2018 and July to September 2019). The areas of the experiments (2018 and 2019) were arranged in parallel and spaced approximately $20 \mathrm{~m}$ apart.

According to the Köppen classification, the region has a tropical altitude climate (Am) with an average temperature of $26.2^{\circ} \mathrm{C}$, average annual precipitation of 2,500 $\mathrm{mm}$ and relative humidity between 75 and $89 \%$ (INMET, 2020). During the experimental period, data on temperature and precipitation (Figure 1) were obtained from the Automatic Surface Observation Meteorological Station of the National Institute of Meteorology (INMET), located at UFRA (CCP).

Prior to the installation of the experiment in 2018, 15 simple samples $(0-0.20 \mathrm{~m})$ were randomly collected with Dutch auger to form a composite sample of the soil in the area. This soil sample was sent to the laboratory to deter-

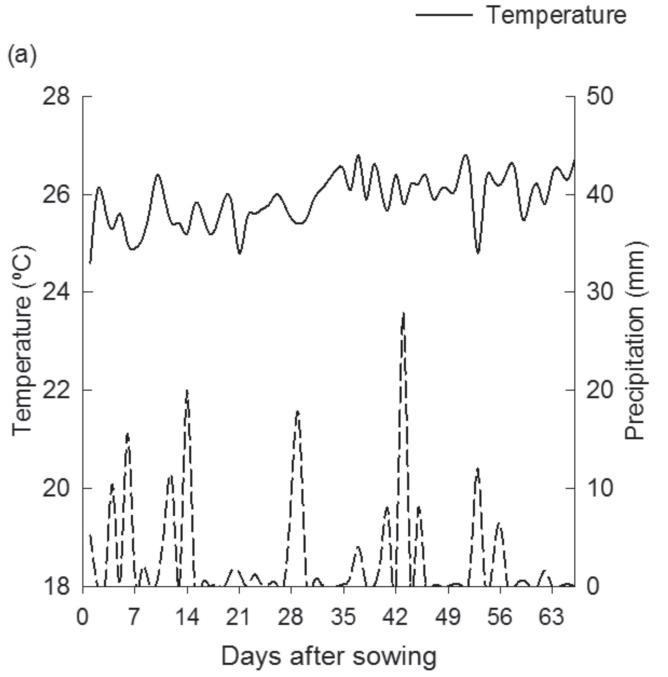

mine its granulometry: $834 \mathrm{~g} \mathrm{~kg}^{-1}$ of total sand, $46 \mathrm{~g} \mathrm{~kg}^{-1}$ of silt and $120 \mathrm{~g} \mathrm{~kg}^{-1}$ of clay, which is characteristic of soft sandy soils. The results of the chemical characterization of the soil in the experimental areas are shown in Table 1. All soil analyzes were performed in the Soil Laboratory of Embrapa Amazônia Oriental (Belém-PA).

The experiment was conducted in a randomized block design (RBD) with four replications, using a split plot scheme. Two cowpea cultivars, BRS Tapaihum (C1) and BRS Marataoã (C2), were cultivated in the main plots and six fertilization and liming treatments were applied in each experimental subplots: i) without fertilization and without liming (T1); ii) $\mathrm{P}$ and $\mathrm{K}$ mineral fertilization, liming and seed inoculation with Rhizobium (T2); iii) P and K mineral fertilization and seed inoculation with Rhizobium (T3); iv) N, P and K mineral fertilization and liming (T4); v) P and $\mathrm{K}$ mineral fertilization and liming (T5); and vi) N, P and $\mathrm{K}$ mineral fertilization, liming and seed inoculation with Rhizobium (T6).

In both experiments, soil preparation was carried out at 44 days before sowing at the end of the rainy season in the Amazon region and consisted of two harrows and liming. Dolomitic limestone (total neutralization power $=$ $92 \%$ ) was incorporated in the $0-0.20 \mathrm{~m}$ layer in the plots $\mathrm{T} 2, \mathrm{~T} 4, \mathrm{~T} 5$ and $\mathrm{T} 6$, in order to reduce the saturation by $\mathrm{Al}^{3+}$ to $20 \%$ (Cravo \& Souza, 2007). Three seeds were sowed per hole at $0.2 \times 0.6 \mathrm{~m}$ spacing. After emergence, two plants were left per hole $\left(166,667\right.$ plants ha $\left.{ }^{-1}\right)$. The experimental plots were composed of six sowing lines of 5 $\mathrm{m}$ each and the two central lines were selected for the evaluations, excluding $1 \mathrm{~m}$ at the ends of each line.

Seeds were inoculated one hour before sowing, with inoculant "TotalNitro Bean-cowpea" (Bradyrhizobium sp.), registered with MAPA(PR 93923 10060-1), which was provided by Total Biotecnologia. A dose of $2 \mathrm{~mL} \mathrm{~kg}^{-1}$ of

- - Precipitation

(b)

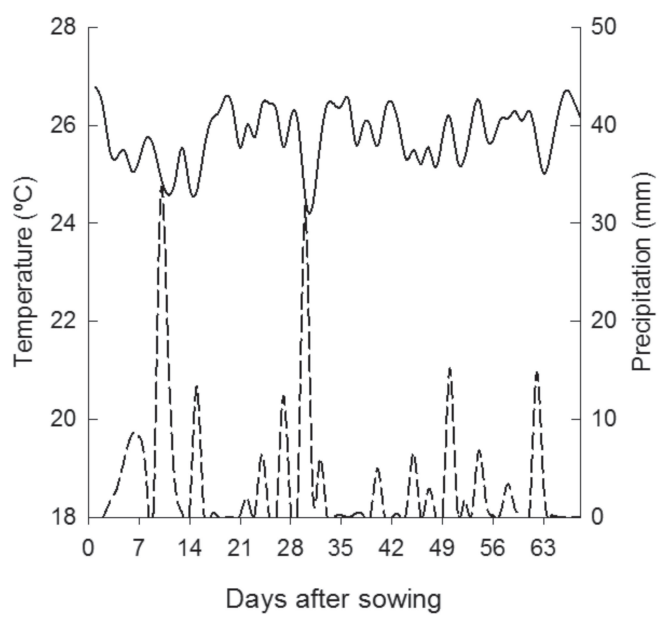

Figure 1: Average air temperature $\left({ }^{\circ} \mathrm{C}\right)$ and precipitation $(\mathrm{mm})$ in Capitão Poço (PA) during the first (A) and second year (B) of cowpea cultivation. Source: INMET, 2020. 
seeds was used following the manufacturer's recommendation. For treatments T4 and T6, $20 \mathrm{~kg} \mathrm{ha}^{-1}$ of $\mathrm{N}$ (urea) were applied as top dressing at 27 days after sowing (Cravo \& Souza, 2007), performing the incorporation of the fertilizer in the soil $(0.05 \mathrm{~m})$ at the beginning of the day period at lower temperature and, subsequently, irrigated. For the mineral fertilization of $\mathrm{P}$ (exception T1), $70 \mathrm{~kg} \mathrm{ha}^{-1}$ of $\mathrm{P}_{2} \mathrm{O}_{5}$ were applied as simple superphosphate on the day of sowing. For mineral fertilization of $\mathrm{K}$ (exception T1), a dose of $60 \mathrm{~kg} \mathrm{ha}^{-1}$ of $\mathrm{K}_{2} \mathrm{O}$ was applied as potassium chloride, which was divided in two equal applications; the first application at day of planting (along with $\mathrm{P}$ application) and the second one at 27 days after planting (along with $\mathrm{N}$ application). The mineral fertilization of $\mathrm{N}, \mathrm{P}$ and $\mathrm{K}$ followed the recommendation of the culture in the state of Pará (Cravo $\&$ Souza, 2007), performing all fertilizations in each pit of the plants. All mineral fertilizers were applied manually to the seeding line at a depth of approximately $0.05 \mathrm{~m}$ from the soil surface. During the experiments, due to the oscillation of precipitation observed in the region (Figure 1), on days when there was no rain the plants were irrigated (localized micro sprinkler irrigation) on alternate days at an average flow of $18.8 \mathrm{~mm} \mathrm{~h}^{-1}$.

Weed control was carried out 14 days before sowing, using the herbicide $\mathrm{N}$ - (phosphonomethyl) grycine (glyphosate isopropylamine salt) $\left(480 \mathrm{~g} \mathrm{~L}^{-1}\right)$ at a dose of 1 $\mathrm{L} \mathrm{ha}^{-1}$. Weeding was also necessary at the end of the vegetative phase of the plants. To prevent the attack of fungi, Carbendazim $\left(500 \mathrm{~g} \mathrm{~L}^{-1}\right)$ was applied at a dose of 0.5 $\mathrm{L} \mathrm{ha}^{-1}$. There were no outbreaks of insect pests in the experiments and, therefore, control was not necessary.

At 46 days after sowing (beginning of the reproductive period), the growth of cowpea was evaluated by plant height (PH), stem diameter (SD), number of leaves (NL) and the ration $\mathrm{PH} / \mathrm{SD}$. Plant height was obtained with the aid of a graduated ruler, SD with the aid of a digital caliper, NL by simple counting. The production of cowpea was evaluated at the end of the experiments (68 days after sowing) by the number of pods per plant (NP), pod length (PL), pod weight (PW), number of grains (NG), grain weight (GW) and grain yield (GY). To measure NP and NG, a simple count was performed. As for PW and GW, a semi-analytical balance was used. For the PL, a graduated ruler was used and GY was estimated from $\mathrm{GW}$ and the number of plants per plot, in which the values were extrapolated to $\mathrm{tha}^{-1}$.

After meeting the assumptions of normality and homoscedasticity, the data were submitted to Analysis of Variance (ANOVA). Regarding the significance of the F test, the means were compared using the Tukey test. Analyzes were performed using Agroestat software (Barbosa \& Maldonato Junior, 2015) and tested at 5\% probability level.

\section{RESULTS AND DISCUSSION}

The plant height (PH) in 2018 was higher for BRS Marataoã (C2) (Figure 2a) and, in 2019, PH did not differ between cultivars (Figure 2b). For both cultivation years, plants grew less in height when cultivated in the absence of liming and fertilization (T1) (Figures 2a and $2 b)$. This fact highlights the importance of correcting the acidity of the soil in order to neutralize $\mathrm{Al}^{3+}$ and increase the availability of nutrients (Cravo et al., 2012), with consequent plant growth. In 2018, the absence of lime application (T3) also promoted low PH (Figure 2a), indicating that for the greater efficiency of rhizobia the correction of soil acidity is essential. Studies carried out with nitrogen fertilization on cowpea have shown plant height of approximately $0.4 \mathrm{~m}$ (Monteiro et al., 2010). Silva et al. (2019), by evaluating the efficiency of rhizobia strains on BRS Marataoã cultivar found values close to $0.35 \mathrm{~m}$ of $\mathrm{PH}$. The average values for PH were 0.31 and $0.24 \mathrm{~m}$, for 2018 and 2019, respectively (Figures 2a and 2b).

The combined supply of mineral and biological $\mathrm{N}$ fertilization (T6) did not decrease $\mathrm{PH}$ in both years of cultivation, since it was used a low dose of mineral N (20 $\mathrm{kg} \mathrm{ha}^{-1}$ ) and it was applied at 27 days after the inoculation of the seeds with rhizobacteria. A study carried out with cowpea indicated that the excessive use of mineral $\mathrm{N}$ fertilization in supplementation has reduced the efficiency of NBF (Brito et al., 2011). There were similar values of PH when $\mathrm{N}$ was supplied via mineral fertilization (T4) or inoculation of seeds with rhizobia (T2).

In 2018 and 2019, stem diameter (SD) presented higher values for the cultivar BRS Tapaihum (C1) and there were lower values only when liming and fertilization was not applied (Figures 2c and 2d). The SD of cowpea in both cultivation years also did not differ between the treatments with mineral and/or biological nitrogen fertilization, indicating the capacity of the rhizobia to supply the demand of $\mathrm{N}$ of the plants. Nitrogen directly interferes with the metabolism of vegetables because it is a constituent of amino acids and proteins capable of increasing the vegetative growth of plants (Dechen \& Nachtigall, 2007; Souza \& Fernandes, 2018). The supply of $\mathrm{N}$ was able to promote greater vegetative growth of cowpea both by mineral and biological fertilization in both cultivation years. Studies with rhizobia in cowpea indicated their capacity to supply the $\mathrm{N}$ demand of plants, similarly replacing mineral fertilizers (Brito et al., 2011).

For the ratio between plant height and stem diameter (PH/SD) cultivar $\mathrm{C} 2$ showed higher values and there were no differences between fertilization and liming treatments for that variable in both evaluated years (Figures $3 \mathrm{a}$ and $3 b$ ). The values of $\mathrm{PH} / \mathrm{SD}$ in both cultivations were higher 
than 3.5 and without prejudice to the development of the plants. Roza \& Rosa (2016) stated that cowpea is a rustic species capable of adapting under adverse conditions. However, it requires liming and fertilization practices to obtain satisfactory grain production. Plant growth studies have determined the ideal $\mathrm{PH} / \mathrm{SD}$ range of 3.5 to 4 and lower values are indicative of low growth (Marana et al., 2008). In this sense, it is essential to establish a growing balance between the $\mathrm{PH}$ and SD for great plant development. The cultivar with the lowest PH (C1) (Figure 2a) was precisely the one that obtained the lowest $\mathrm{PH} /$ SD quotient (Figure 3a).

(a)

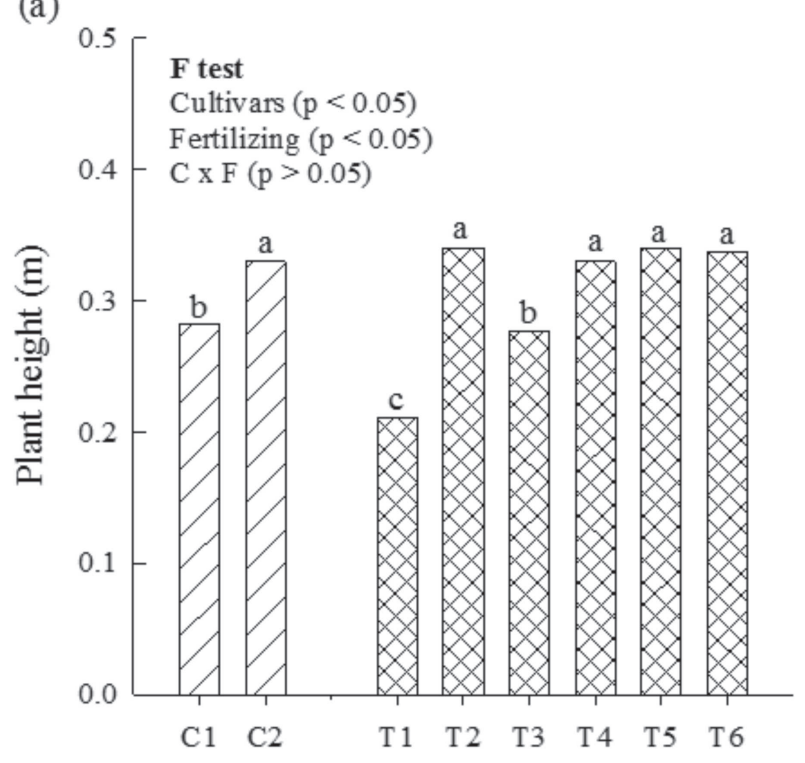

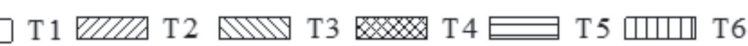

(c)

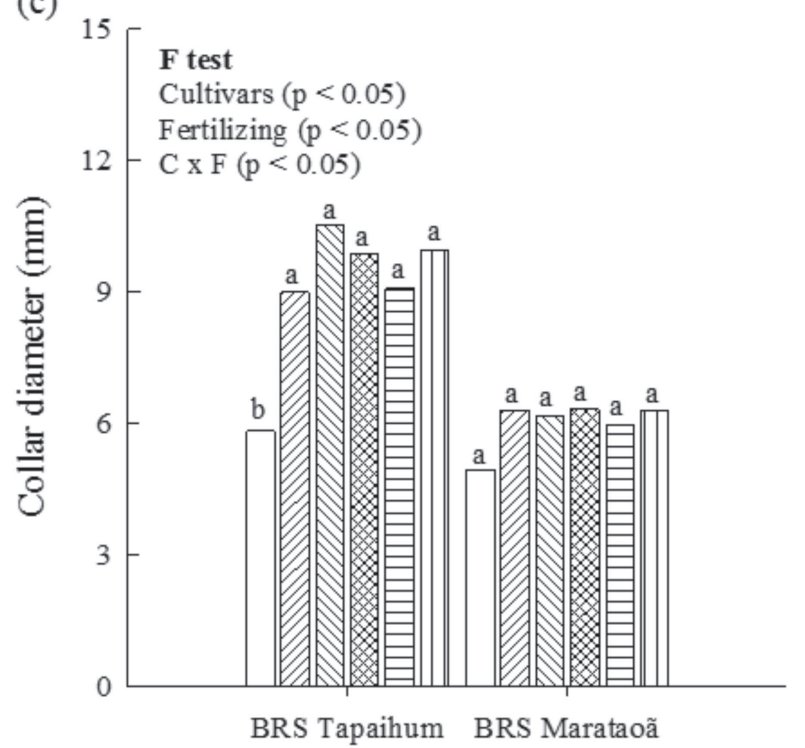

Regarding the number of leaves (NL), there were no differences between cultivars in the first year of the experiment and, in 2019, NL was higher in cultivar C1 (Figures $3 \mathrm{c}$ and $3 \mathrm{~d}$ ). The NL of the studied cultivars were lower in plots that did not receive fertilization and liming (T1), both in 2018 and 2019. In 2018, for C2, there was also less $\mathrm{NL}$ in the absence of liming, but with the inoculation of seeds with rhizobia (T3), this is an indication of the importance of correcting soil acidity to increase the efficiency of NBF. The increase in soil $\mathrm{pH}$ by liming increases the activity of bacteria (Soares et al., 2014). In 2019, a lower NL was also observed in the treatment without application

(b)

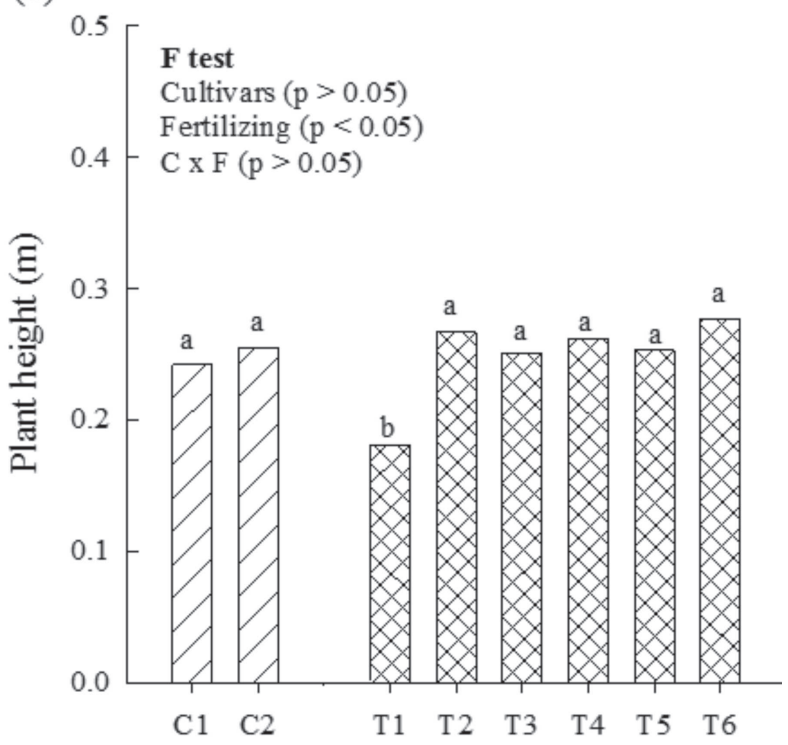

(d)

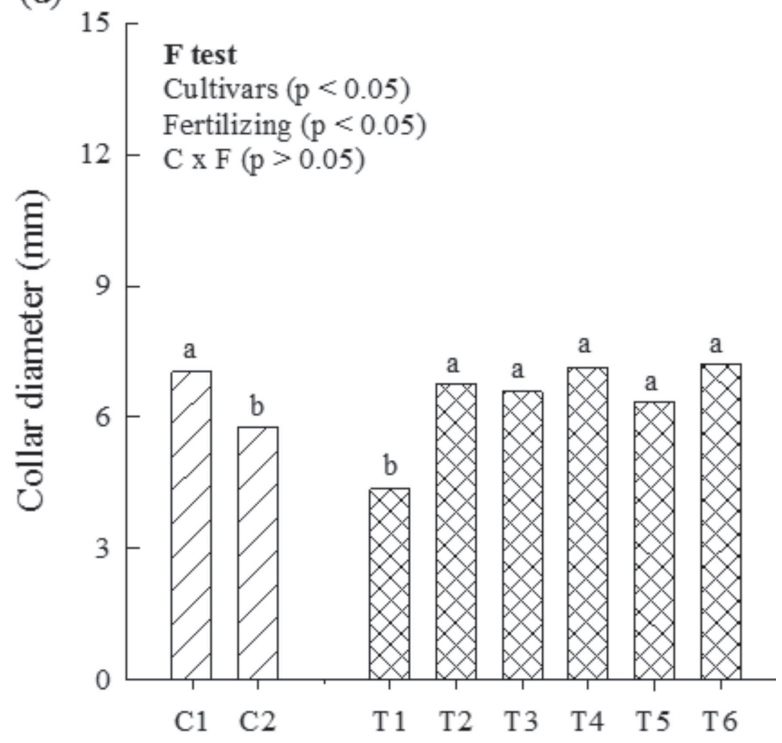

Figure 2: Plant height in 2018 (A) and 2019 (B) and stem diameter in 2018 (C) and 2019 (D) for cowpea cultivars (BRS Tapaihum - C1 and BRS Marataoã - C2) as a function of fertilization and soil correction (Treatments - T). Means comparing cultivars and fertilization treatments followed by the same letter do not differ from each other by the Tukey test $(\mathrm{p}>0.05)$. 
of $\mathrm{N}$ (T5) when compared with treatments with the presence of N (T2, T3, T4 and T6) (Figure 3d). This indicates the effect of this nutrient in increasing leaf growth. The absorbed $\mathrm{N}$ is incorporated into plants as amino acids and, later, transformed into proteins capable of promoting leaf growth and increasing the photosynthetic area in vegetables (Dechen \& Nachtigall, 2007).

For the variables number of pods (NP) and pods weight (PW) there were no differences between cultivars in both evaluated years. However, for the treatments, there were lower values for the lack of liming and fertilization (Figures $4 \mathrm{a}, 4 \mathrm{~b}, 4 \mathrm{c}$ and $4 \mathrm{~d})$.
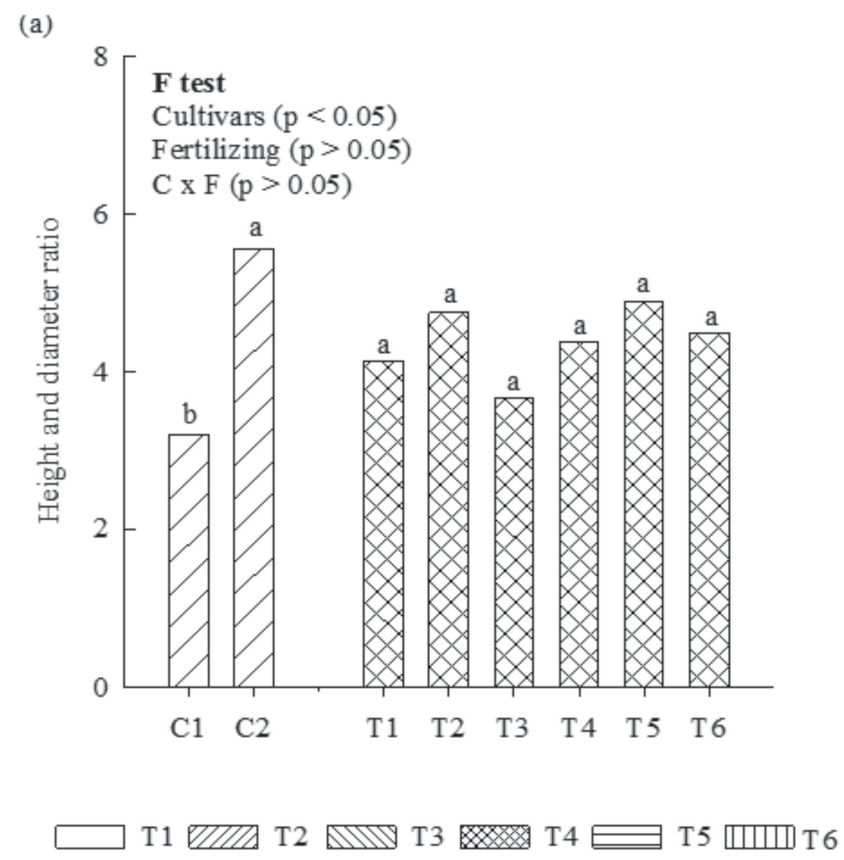

(c)

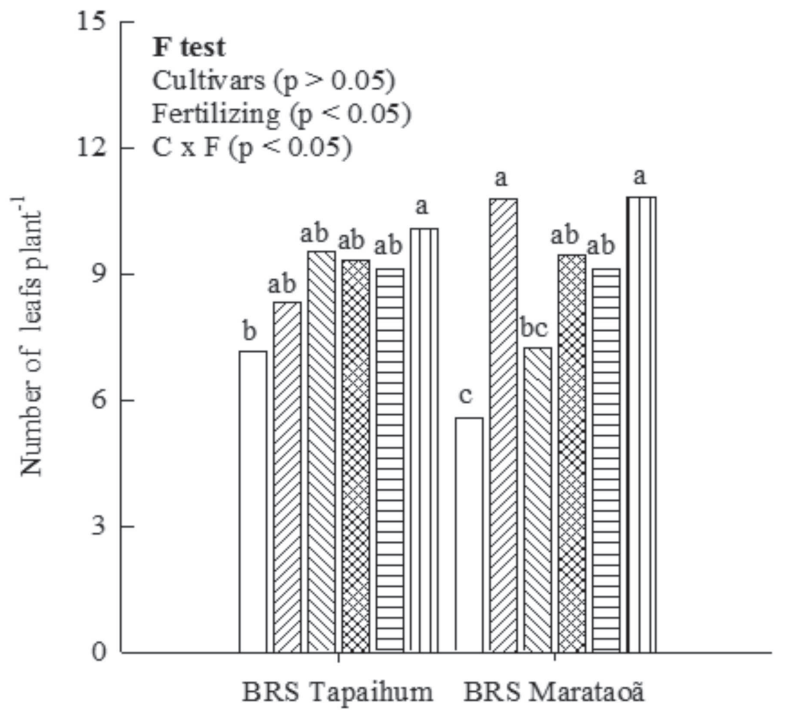

Studies carried out with nitrogen fertilization (mineral or biological) in cowpea suggested that variables such as $\mathrm{NP}$ and PW did not suffer interference from $\mathrm{N}$ sources (Martins et al., 2013). The supply of $\mathrm{N}$ in plants is related to vegetative growth, but its excess can stimulate the overgrowth of plants at the expense of grain production (Martins et al., 2013). In this sense, the supply of $\mathrm{N}$ via mineral and/or biological fertilization did not directly influence the characteristics of NP and PW in both cultivation years (Figures 4a, 4b, 4c and 4d).

Regarding pod length (PL), there were no differences between cultivars in both evaluated years (Figures $4 \mathrm{e}$ and

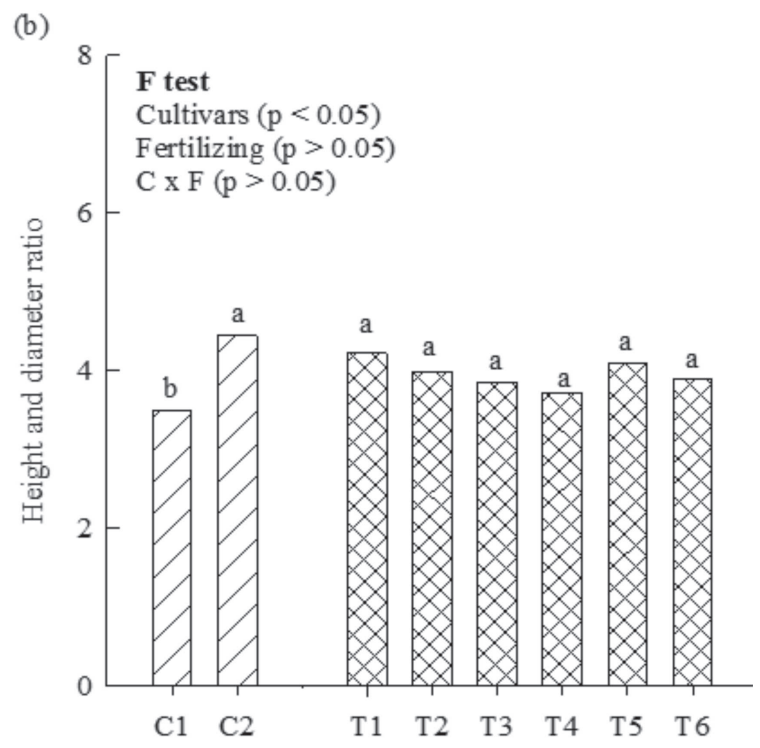

(d)

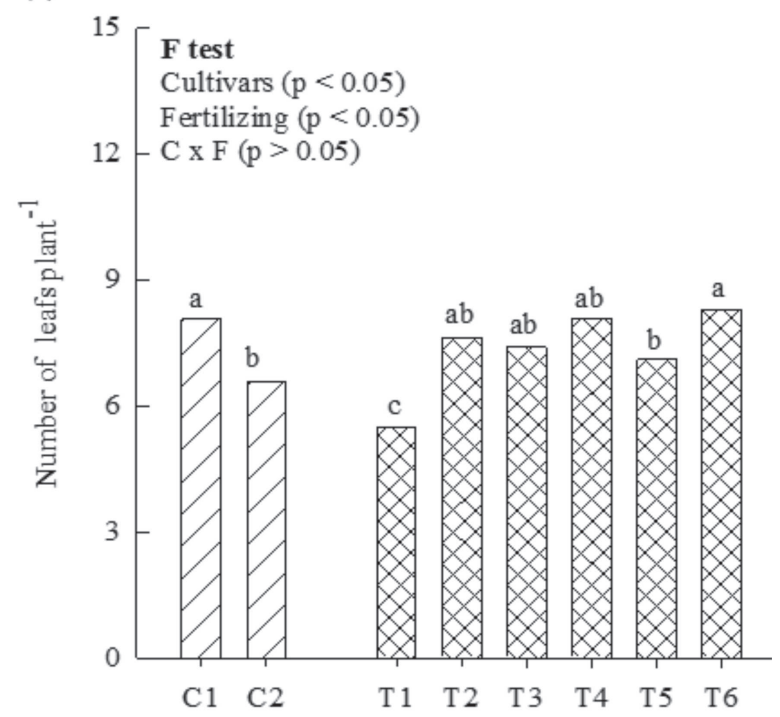

Figure 3: Relationship of height and stem diameter in 2018 (A) and 2019 (B) and number of leaves in 2018 (C) and 2019 (D) for cowpea cultivars (BRS Tapaihum - C1 and BRS Marataoã - C2) as a function of fertilization and soil correction (Treatments - T). Means comparing cultivars and fertilization treatments followed by the same letter do not differ from each other by the Tukey test $(\mathrm{p}>0.05)$.

Rev. Ceres, Viçosa, v. 68, n.5, p. 460-470, sep/oct, 2021 

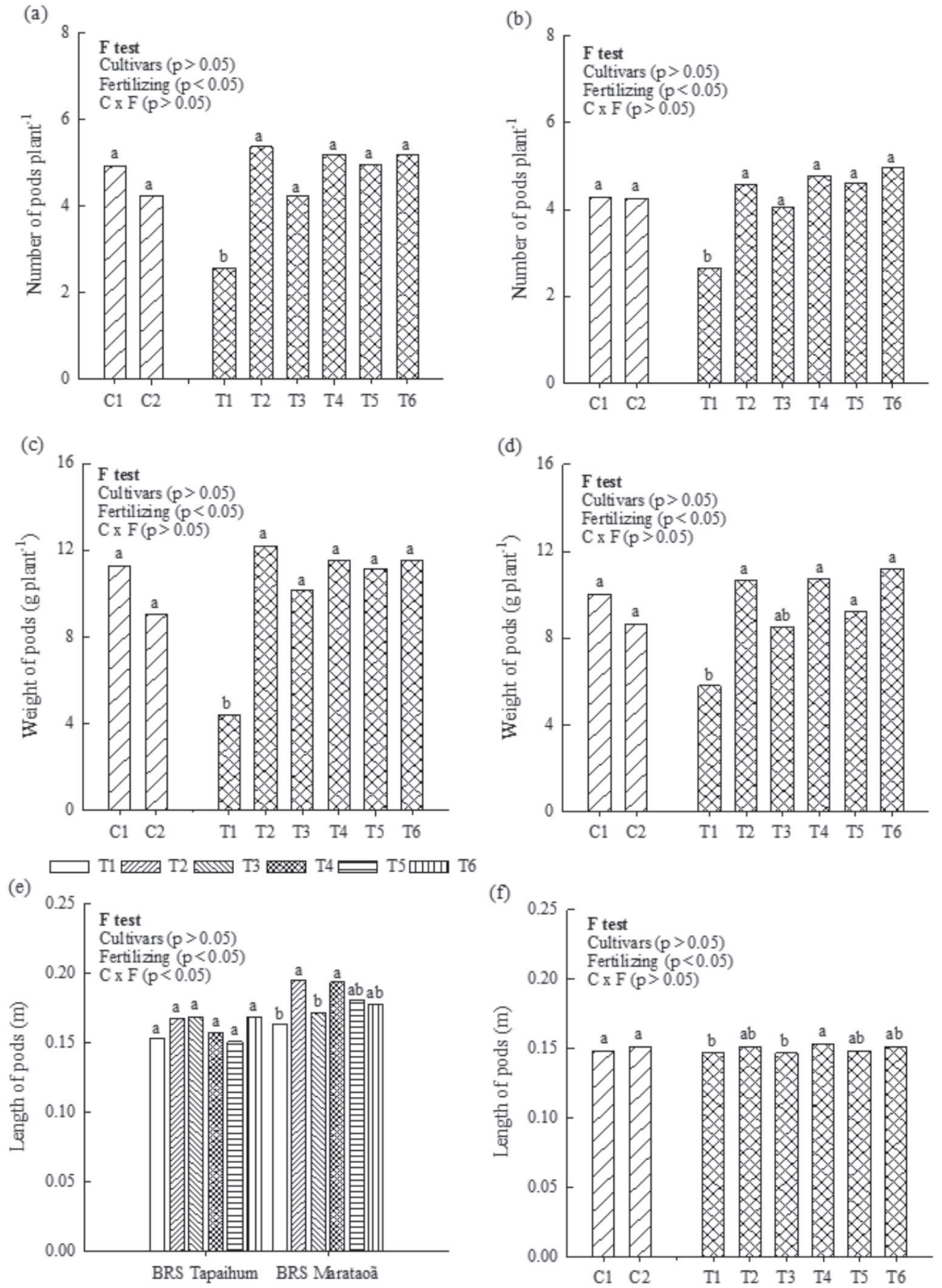

Figure 4: Number of pods in 2018 (A) and 2019 (B), weight of pods in 2018 (C) and 2019 (D), and length of pods in 2018 (E) and 2019 (F) for cowpea cultivars (BRS Tapaihum - C1 and BRS Marataoã - C2) as a function of fertilization and soil correction (Treatments - T). Means comparing cultivars and fertilization treatments followed by the same letter do not differ from each other by the Tukey test $(\mathrm{p}>0.05)$. 
4f). In the first year, cultivar C2 showed higher PL when cultivated in treatments that received liming and/or nitrogen fertilization (mineral and/or biological) (Figure 4e). In 2019, PL was also higher in plants that received liming and/or nitrogen fertilization (T2, T4, T5 and T6) (Figure 4f).

The number of grains (NG), grains weight (GW) and grains yield (GY) did not differ between cultivars for both evaluated years (Figures 5a, 5b, 5c, 5d, 5e and 5f). However, in both periods of evaluation, there was a tendency for a higher $\mathrm{GY}$ of cultivar $\mathrm{C} 1$ when compared with cultivar C2 (Figures 5e and 5f). In 2019, cultivar C1 also had presented higher NL (Figures 3d), which is an indicative of a direct relationship between GY and NL. Higher NL might represent greater leaf area, with consequently higher photosynthetic rates, carbon assimilation and greater plant production. Nitrogen is essential to the physiological activities of beans, present in the chlorophyll molecule, a pigment responsible for the photosynthetic process and for the transformation of nutrients into photoassimilates and grains, with a reflection on the productivity gain (Sorrato et al., 2006). In 2018, there was lower NG, GW and GY in the plants grown in $\mathrm{T} 1$ treatment (Figures 5a, $5 \mathrm{c}$ and $5 \mathrm{e}$ ), while in the second year there were lower values of these variables in $\mathrm{T} 1$ and $\mathrm{T} 3$ (Figures 5b, 5d and 5f).

In 2018, GY was negatively influenced by the absence of liming and fertilization with P and K (T1) (Figure 5e) and, in 2019, also by the lack of soil acidity correction (T3) (Figure 5f). It is important to highlight that when the seeds were inoculated with rhizobia and it was not applied lime (T3), the condition of lower soil $\mathrm{pH}$ and greater $\mathrm{Al}^{+3}$ concentration at second year (Table 1) was most limiting to production of cowpea (Figure 5f). Such observation indicates the importance of liming and the supply of macronutrients $(\mathrm{P}, \mathrm{K}, \mathrm{Ca}$ and $\mathrm{Mg}$ ) to enhance the efficiency of rhizobia to supply $\mathrm{N}$ for cowpea. It is also interesting to note that when comparing T2 and T3 treatments in 2019, there was a decrease in GY in the latter treatment (Figure 5f). This fact indicates the benefit of correcting the acidity of the soil in increasing the $\mathrm{pH}$ and thus NBF, with a contribution in increasing $\mathrm{GY}$ in $\mathrm{T} 2$ when compared with T3. Strategies for increasing NBF in agricultural ecosystems include, among other factors, the use of liming and fertilization (Furtini Neto et al., 2000).

Liming ensures the correction of soil acidity, increases the availability of nutrients to plants, promotes greater efficiency of fertilizers and, finally, results in optimal conditions for crop development (Caires \& Joris, 2016), even for those considered tolerant to relatively high levels of acidity such as cowpea (Furtini Neto et al., 2000).

When liming was performed, there were no differences in the production variables in relation to the supply of $\mathrm{N}$ via seed inoculation (T2), via mineral fertilization (T4) or both (T6) (Figure 5). In both cultivation years, the treatment inoculated with rhizobacteria (T2) and the treatment fertilized with mineral N (T4) obtained the same GY (Figures 5e and 5f). Thus, it is interesting to supply $\mathrm{N}$ via inoculation of cowpea seeds in relation to the application of mineral $\mathrm{N}$, given the relatively lower cost of inoculation. In 2019, the average price of urea (44.4 $\mathrm{kg}$ ), equivalent to $20 \mathrm{~kg} \mathrm{ha}^{-1}$ of $\mathrm{N}$ (recommendation for cowpea; Cravo \& Souza, 2007) in the country was R\$ 69.30 (CONAB, 2020), whereas, depending on the region, the cost to the producer of the inoculant $(100 \mathrm{~mL})$ sufficient for $50 \mathrm{~kg}$ of seeds was only around $\mathrm{R} \$ 5.50$ (Total Biotechnology). Unfortunately, the inoculation of beans with rhizobacteria is a practice still not commonly used by farmers in Brazil, mainly in the northeast region of Pará, especially by the lack of positive results in field conditions (Chagas Junior et al., 2010), making the present work a practical tool for producers in the region. Moreover, despite the application of mineral $\mathrm{N}$ being the main source of supply of this nutrient to cultivated plants, when in high doses, part of the supply is lost due to leaching and volatilization in tropical regions (Sorrato $e t$ al., 2006; Martins et al., 2013), which increases contamination mainly in sandy soil and in a region with high rainfall. In addition, the use of urea as a mineral source of $\mathrm{N}$ must be done with correct management, such as at lower temperatures, incorporation and/or irrigation, otherwise losses of volatile $\mathrm{N}$ can reach $80 \%$ of the total applied (Sangoi et al., 2003), mainly in the region with higher temperatures (Figure 1).

Considering the contribution of NBF by rhizobia to the cowpea culture, seed inoculation was able to supply the $\mathrm{N}$ demand of the plants in a similar way to the supply through mineral fertilization, providing similar responses in grain yield (Zilli et al., 2009; Chaves et al., 2018). Thus, these studies prove that the supply of $\mathrm{N}$ via mineral fertilization or inoculation with rhizobia is able to meet the nutritional demand without difference in GY of cowpea.

There was no response from the production variables to the application of $\mathrm{N}$ (Figures 4 and 5). Similar values were observed between its omission (T5) and its supply (T2, T4 and T6), which cannot be interpreted as a no indication of nitrogen fertilization, since there might be a decrease in the $\mathrm{N}$ reserve in the soil in subsequent crops. Practical observations in the region have indicated a higher frequency of responses to nitrogen fertilization in soils with intensive use and that are cultivated for several years without organic fertilization or green fertilizers (Brasil \& Cravo, 2009), which is not the case of areas of the present study (Table 1). Furthermore, it is necessary to consider replacement fertilization (Cantarella, 2007), which 

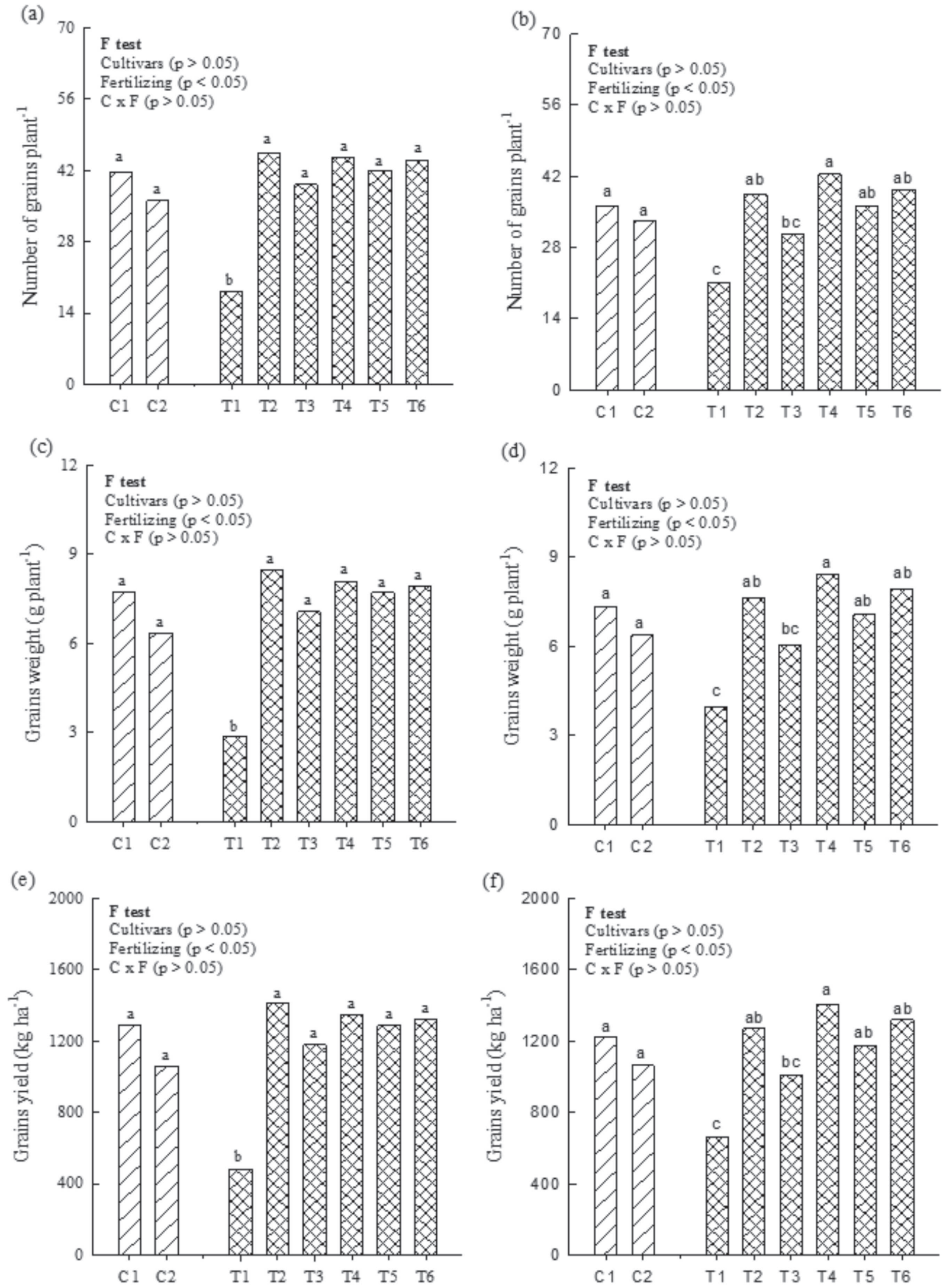

Figure 5: Number of grains in 2018 (A) and 2019 (B), weight of grains in 2018 (C) and 2019 (D), and grain yield in 2018 (E) and 2019 (F) for cowpea cultivars (BRS Tapaihum - C1 and BRS Marataoã - C2) as a function of fertilization and soil correction (Treatments - T). Means comparing cultivars and fertilization treatments followed by the same letter do not differ from each other by the Tukey test $(\mathrm{p}>0.05)$. 
aims to supply the amount of $\mathrm{N}$ exported by the crops. For cowpea, this value is in the order of $30 \mathrm{~kg} \mathrm{ha}^{-1}$ (Randall et al., 2006). Thus, for maintaining the reserve of $\mathrm{N}$ in the soil and due to the environmental aspects already mentioned, it is recommended the inoculation of seeds with rhizobia aiming at the supply of $\mathrm{N}$ to cowpea. Gualter et al., (2008) also found no difference in productivity between inoculated and non-inoculated treatments caused by the ability of native bacteria to perform symbiosis with cowpea. The culture has low specificity of nodulation, being able to obtain different responses of the rhizobia from the conditions of cultivation, cultivars and region (Chagas Junior et al., 2010; Borges et al., 2012). Cowpea BNF fully meets the demand for $\mathrm{N}$ via seed inoculation with rhizobia, being able to replace nitrogenous mineral fertilizers (Brito et al., 2011).

Soil organic matter (SOM) is the main source of $\mathrm{N}$ in the soil for plants and it can represent up to $95 \%$ of the total $\mathrm{N}$ of the soil (Silva \& Mendonça, 2007). Thus, the lack of response of cowpea in production to nitrogen fertilization can be partly explained by the contribution of SOM due to its mineralization, although in soil with low content of SOM (Table 1; Alvarez et al., 1999) and region with high temperatures and rainfall (Figure 1). In newly deforested areas, the organic carbon content might be a good indicator of the $\mathrm{N}$ stock in the soil, allowing its gradual release in the first years of agricultural exploration (Wadt \& Cravo, 2005). About 2 to $3 \%$ of the organic $\mathrm{N}$ in the soil is mineralized annually (Foth \& Ellis, 1996), which represents an annual release of 16 to $180 \mathrm{~kg} \mathrm{ha}^{-1}$ of inorganic $\mathrm{N}$ for different types of Brazilian soils (Cantarella, 2007). The demand for $\mathrm{N}$ from cowpea is in the order of $106 \mathrm{~kg} \mathrm{ha}^{-1}$ (Neves et al., 2009). Estimates of the potentially mineralizable $\mathrm{N}$ in Oxisols and Neossols in the state of Goiás indicate that this fraction represents less than $2 \%$ of the total N of the soils (Silva \& Mendonça, 2007), although management practices such as liming can increase the mineralization rate of the N of SOM (Silva et al., 1999), meeting the demand for crops regarding the nutrient. In addition, liming can contribute to increasing the content of N and NBF (Fonseca et al., 2010), thus in soils with low SOM content the $\mathrm{N}$ mineralized is not sufficient to supply the demand for cowpea (Table 1). In this sense, liming provided greater grain production to cowpea (Figure 5), which can be explained by the increases the levels of soil $\mathrm{N}$ by correcting the soil acidity (Fonseca et al., 2010) because of the $\mathrm{pH}$ increase and acceleration of the mineralization process of SOM.

In addition, wetting the dry soil can stimulate mineralization and cause a peak release of available $\mathrm{N}$ (Foth \& Ellis, 1996). This fact might have occurred in the present study once the areas were irrigated. Additionally, the mineralization of organic $\mathrm{N}$ is stimulated by the addition of nitrogen fertilizers (priming effect), which increases the availability of $\mathrm{N}$ in the soil from SOM, in addition to the revolving of the soil reducing the stock of organic $\mathrm{N}$ over time (Cantarella, 2007). However, the immobilization of $\mathrm{N}$ carried out by microorganisms occurs concomitantly with its mineralization. There is a condition of balance between these two processes when the $\mathrm{C} / \mathrm{N}$ ratio of the substrate is in the range of 20 to 30 , this fact influences the availability of $\mathrm{N}$ for the crops and the way, season and dose of fertilizer applied (Cantarella, 2007). In 2018 and 2019, the C/N ratio in the soil was 10/1 and 12/1 (Table 1), respectively, which favored mineralization rather than immobilization, which must have increased the release of $\mathrm{N}$ from SOM for plant absorption and decreased dependence on $\mathrm{N}$ added via fertilizer.

Finally, it is noteworthy that even though there was no significant response in $\mathrm{GY}$ to the application of $\mathrm{N}$ in both cultivation years (Figures $5 \mathrm{e}$ and $5 \mathrm{f}$ ), there was a numerical difference in GY when comparing the treatment without supply of N (T5) to the treatments with its application (T2, T4 and T6). This difference can be practical order for the producer. For example, in 2019, there was GY of $1,177 \mathrm{~kg}$ ha-1 in T5 and $1,270 \mathrm{~kg} \mathrm{ha}^{-1}$ in the treatment with seed inoculation with rhizobia (T2), difference of $93 \mathrm{~kg} \mathrm{ha}^{-1}$ for the farmer, with emphasis again for the importance of nitrogen fertilization for the cultivation of cowpea in the region (Cravo \& Souza, 2007). Moreover, high grain yields were verified in the present study, mainly in the treatments with fertilization and liming (T2, T4, T5 and T6) (Figures 5e and 5f), when compared with the averages of the municipality of Capitão Poço $\left(585 \mathrm{~kg} \mathrm{ha}^{-1}\right)$, Pará $\left(776 \mathrm{~kg} \mathrm{ha}^{-1}\right)$ and Brazil (493 kg ha-1) (IBGE, 2017). Unfortunately, liming and fertilizing practices

Table 1: Chemical characterization of the soil ( 0 to $0.20 \mathrm{~m}$ ) of the area immediately before the installation of the experiments in 2018 and 2019

\begin{tabular}{|c|c|c|c|c|c|c|c|c|c|c|c|}
\hline \multirow{3}{*}{$\underline{\text { Year }}$} & \multirow{2}{*}{$\frac{\mathrm{pH}}{\left(\mathbf{H}_{2} \mathrm{O}\right)}$} & $\mathbf{P}$ & $\mathbf{K}$ & $\mathrm{Ca}^{+2}$ & $\mathbf{M g}^{+2}$ & $\mathbf{A l}^{+3}$ & $\mathbf{H}+\mathbf{A l}$ & SOC & $\mathbf{N}$ & V & $\mathbf{m}$ \\
\hline & & \multicolumn{2}{|c|}{$\mathrm{mg} \mathrm{dm}^{-3}$} & \multicolumn{4}{|c|}{$\mathrm{cmol}_{\mathrm{c}} \mathrm{dm}^{-3}$} & \multicolumn{4}{|c|}{$\%$} \\
\hline & 5.11 & 2 & 21 & 0.34 & 0.11 & 0.55 & 3.97 & 0.62 & 0.06 & 12.36 & 49.53 \\
\hline 2019 & 4.60 & 3 & 13 & 0.47 & 0.20 & 0.61 & 4.39 & 0.87 & 0.07 & 14.07 & 45.93 \\
\hline
\end{tabular}

$\mathrm{pH}$ in water (ratio 1:2.5). $\mathrm{P}$ and $\mathrm{K}$ extraction by Mehlich-1. $\mathrm{Ca}^{+2}, \mathrm{Mg}^{+2}$ and $\mathrm{Al}^{+3}$, extraction by $\mathrm{KCl}\left(1 \mathrm{~mol} \mathrm{~L}^{-1}\right) . \mathrm{H}+\mathrm{Al}$ extraction by buffered calcium acetate at $\mathrm{pH} 7,0$. Soil organic carbon (SOC) - extraction by sodium dichromate and sulfuric acid. Total nitrogen (N) - sulfuric digestion / method Kjeldahl. V- Bases saturation. m - Aluminum saturation. 
are still rarely used in the region, only $18.8 \%$ of rural establishments use these practices in the state of Pará (IBGE, 2017). In both cultivation years of cowpea there was an average of $1320 \mathrm{~kg} \mathrm{ha}^{-1}$ of GY for treatments with fertilization and liming (T2, T4, T5 and T6) (Figures 5e and 5f), which represents $70 \%$ more in relation to the average GY of Pará (IBGE, 2017). This fact proves the importance of adopting soil management practices, such as fertilization and liming, in increasing the productivity of the crop in the region, with a consequent gain for producers.

\section{CONCLUSIONS}

The lack of soil acidity correction and mineral fertilization with $\mathrm{P}$ and $\mathrm{K}$ proved to be limiting to the growth and production of cowpea.

There was no plant response to nitrogen fertilization. However, it is suggested to inoculate the seeds with rhizobia due to less environmental impact and lower cost in order to maintain the $\mathrm{N}$ reserve in the soil over time.

In general, the cultivars Tapaihum and Marataoã differed in growth, but not in the production variables.

\section{ACKNOWLEDGEMENTS, FINANCIAL SUPPORT AND FULL DISCLOSURE}

To the farmer Benedito Dutra and to Embrapa, for the donation of seeds, and to the company Total Biotecnologia, for the concession of the inoculant. To the National Council for Scientific and Technological Development (CNPq) for the scholarship provided to the first author. To the Campus of Capitão Poço of the Federal Rural University of the Amazon, for the logistical and infrastructure support.

\section{REFERENCES}

Alvarez VH, Novais RF, Barros NF, Cantarutti RB \& Lopes AS (1999) Interpretação dos resultados das análises de solos. In: Ribeiro AC, Guimarães PTG \& Alvarez VH (Ed.) Recomendações para o uso de corretivos e fertilizantes em Minas Gerais. Viçosa, Comissão de Fertilidade do Solo do Estado de Minas Gerais. p.25-32.

Barbosa JC \& Maldonado Junior W (2015) AgroEstat - sistema para análises estatísticas de ensaios agronômicos. Jaboticabal, FCAV/UNESP. 396p.

Brasil EC \& Cravo MS (2009) Recomendação de Adubação e Calagem para o Estado do Pará: A Importância do Uso Racional de Fertilizantes e Calcário. Revista de Estudos Paraenses, 2:5566.

Brito LF, Pacheco RS, Souza Filho BF, Ferreira EPB, Straliotto R \& Araújo AP (2015) Resposta do feijoeiro comum à inoculação com rizóbio e suplementação com nitrogênio mineral em dois biomas brasileiros. Revista Brasileira de Ciência do Solo, 39:981992.

Brito MMP, Muraoka T \& Silva EC (2011) Contribuição da fixação biológica de nitrogênio, fertilizante nitrogenado e nitrogênio do solo no desenvolvimento de feijão e caupi. Bragantia, 70:206-215.
Borges PRS, Saboya RCC, Saboya LMF, Santos ER \& Souza SEA (2012) Distribuição de massa seca e rendimento de feijãocaupi inoculadas com rizóbio em Gurupi, TO. Revista Caatinga, 25:37-44.

Caires EF \& Joris HAW (2016) Uso de corretivos granulados na agricultura. International Plant Nutrition Institute, 154:17-21.

Cantarella H (2007) Nitrogênio. In: Novais RF, Alvarez VH, Barros NF, Fontes RLF, Cantarutti RB \& Neves JCL (Ed.) Fertilidade do solo. Viçosa, Sociedade Brasileira de Ciência do Solo. p.375-470.

Chagas Junior AF, Rahmeier W, Fidelis RR, Santos GR \& Chagas LFB (2010) Eficiência agronômica de estirpes de rizóbio inoculadas em feijão-caupi no Cerrado, Gurupi-TO. Revista Ciência Agronômica, 41:709-714.

Chakirwa ZP, Addo SJ, Gyapong AT, Lubobo AK \& Bashagaluke BJ (2019) Growth, Nodulation and Nutrients Uptakes of Cowpea (Vigna unguiculata L. Walp) following Zinc Fertilizer Applications in the Semi-deciduous Forest Zone of Ghana. Journal of Experimental Agriculture International, 35:1-13.

Chaves JS, Oliveira GA, Rodrigues TG, Maia SS, Teixeira Junior DL, Sousa FG \& Rodriguez CA (2018) Produtividade do feijãocaupi sob inoculação em área alterada no estado de Roraima Brasil. Nucleus, 15:319-324.

Cravo MS, Smyth TJ \& Brasil, EC (2012) Calagem em Latossolo amarelo distrófico da amazônia e sua influência em atributos químicos do solo e na produtividade de culturas anuais. Revista Brasileira de Ciência do Solo, 36:895-907.

Cravo MS \& Souza BDL (2007) Feijão-caupi. In Cravo MS, Viégas IJM \& Brasil EC (Ed.) Recomendações de adubação e calagem para o Estado do Pará. Belém, Embrapa Amazônia Oriental. p.147-149

CONAB (2020) Acompanhamento da safra brasileira de grãos - safra 2019/20. Available at: https://www.conab.gov.br/info-agro/safras/ graos/boletim-da-safra-de-graos). Accessed on: April 3 $3^{\text {rd }}, 2020$.

Dechen AR \& Nachtigall GR (2007) Elementos requeridos à nutrição de plantas. In Novais RF, Alvarez VH, Barros NF, Fontes RLF, Cantarutti RB \& Neves JCL (Ed.) Fertilidade do solo. Viçosa, Sociedade Brasileira de Ciência do Solo. p.91-132

Farias TP, Trochmann A, Soares BL \& Moreira FMS (2016) Rhizobia inoculation and liming increase cowpea productivity in Maranhão State. Acta Scientiarum Agronomy, 38:387-395.

Fonseca MR, Fernandes AR, Silva GR \& Brasil EC (2010) Teor e acúmulo de nutrientes por plantas de feijão caupi em função do fósforo e dasaturação por bases. Revista de Ciências Agrárias, 53:195-205.

Foth HD \& Ellis BG (1996) Soil fertility. Boca Raton, Lewis Publishers. 290p.

Furtini Neto AE, Siqueira JO, Curi N \& Moreira FMS (2000) Fertilização em reflorestamento com espécies nativas. In: Gonçalves JLM \& Benedetti V (Ed.) Nutrição e fertilização florestal. Piracicaba, IPEF. p.351-383.

Gualter RMR, Leite LFC, Araújo ASF, Alcântara RMCM \& Costa DB (2008) Inoculação e adubação mineral em feijão-caupi: efeitos na nodulação, crescimento e produtividade. Scientia Agraria, 9:469-474.

Gualter RMR, Boddey RM, Rumjanek NG, Freitas ACR \& Xavier GR (2011) Eficiência agronômica de estirpes de rizóbio em feijão-caupi cultivado na região da Pré-Amazônia Maranhense. Pesquisa Agropecuária Brasileira, 46:303-308.

IBGE (2017) Censo agropecuário. Available at: https:// cidades.ibge.gov.br/brasil /pa/capitaopoco/pesquisa/24/ 76693 ? localidade $1=15$ andlocalidade2=0). Accessed on: April $24^{\text {th }}, 2020$. 
INMET (2020) Estações automáticas. Available at: http:// www.inmet.gov.br/portal /index. php?r=estacoes/estacoesAutomaticas). Accessed on: April 4 ${ }^{\text {th }}, 2020$.

Marana JP, Miglioranza E, Fonseca EP \& Kainuma RH (2008) Índices de qualidade e crescimento de mudas de café produzidas em tubetes. Ciência Rural, 38:39-45.

Martins RNL, Nóbrega RSA, Silva AFT, Nóbrega JCA, Amaral FHC, Costa EM, Lustosa Filho JF \& Martins LV (2013) Nitrogênio e micronutrientes na produção de grãos de feijão-caupi inoculado. Semina: Ciências Agrárias, 34:1577-1586.

Melo SR \& Zilli JE (2009) Fixação biológica de nitrogênio em cultivares de feijão-caupi recomendadas para o Estado de Roraima. Pesquisa Agropecuária Brasileira, 44:1177-1183.

Monteiro PFC, Ângulo Filho R \& Monteiro ROC (2010) Efeitos da irrigação e da adubação nitrogenada sobre as variáveis agronômicas da cultura do feijão. Irriga, 15:386-400.

Neves ALR, Lacerda CF, Guimarães FVA, Hernandez FFF, Silva FB, Prisco JT \& Gheyi HR (2009) Acumulação de biomassa e extração de nutrientes por plantas de feijão-de-corda irrigadas com água salina em diferentes estádios de desenvolvimento. Ciência Rural, 39:758-765.

Randall PJ, Abaidoo RC, Hocking PJ \& Sanginga N (2006) Mineral nutrient uptake and removal by cowpea, soyben and maize cultivars in west Africa, and implications for carbono cycle effects on soil acidification. Experimental Agricultural, 42:475495 .

Roza RA \& Rosa JS (2016) A cooperativa agropecuária dos Cincos Polos - Coopercinco e o apoio a produção de feijão-caupi no PA Nova Amazônia. Revista de Administração de Roraima, $6: 738-751$

Sangoi L, Ernani PR, Lech VA \& Rampazzo C (2003) Volatilização de N-NH3 em decorrência da forma de aplicação de uréia, manejo de resíduos e tipo de solo, em laboratório. Ciência Rural, 33:687-692.
Silva EM, Santos MM, Lopes MBS, Fidelis RR, Rocha WS \& Chagas Junior AF (2019) Eficiência de rizóbio sob doses de fósforo na cultura do feijão-caupi. Revista brasileira de Agropecuária Sustentável, 9:67-77.

Silva IR \& Mendonça ES (2007) Matéria Orgânica do Solo. In: Novais RF, Alvarez VH, Barros NF, Fontes RLF, Cantarutti RB \& Neves JCL (Ed.) Fertilidade do solo. Viçosa, Sociedade Brasileira de Ciência do Solo. p.275-374.

Silva MF, Santos CERS, Sousa CA, Araújo RSL, Stamford NP \& Figueiredo MVB (2012) Nodulação e eficiência da fixação do N2 em feijão-caupi por efeito da taxa do inóculo. Revista Brasileira de Ciência do Solo, 36:1418-1425.

Silva CA, Vale FR, Anderson SJ \& Kobal AR (1999) Mineralização de nitrogênio e enxofre em solos brasileiros sob influência da calagem e fósforo. Pesquisa Agropecuária Brasileira, 34:16791689.

Soares BL, Ferreira PAA, Oliveira Longatti SM, Marra LM, Rufini M, Andrade MJB \& Moreira FMS (2014) Cowpea symbiotic efficiency, $\mathrm{pH}$ and aluminum tolerance in nitrogen-fixing bacteria. Scientia Agricola, 71:171-180.

Soratto RP, Carvalho MAC \& Arf O (2006) Nitrogênio em cobertura no feijoeiro cultivado em plantio direto. Revista Brasileira de Ciência do Solo, 30:259-265.

Souza SR \& Fernandes MS (2018) Nitrogênio. In: Fernandes MS, Souza SR \& Santos LA (Ed.) Nutrição Mineral de Plantas. Viçosa, Sociedade Brasileira de Ciência do Solo. p.309-376.

Wadt PGS \& Cravo MS (2005) Interpretações de resultados de análises de solos. In: Wadt PGS (Ed.) Manejo do solo e recomendação de adubação para o estado do Acre. Rio Branco, Embrapa Acre. p.245-252

Zilli JE, Marson LC, Marson BF, Rumjanek NG \& Xavier GR (2009) Contribuição de estirpes de rizóbio para o desenvolvimento e produtividade de grãos de feijão-caupi em Roraima. Acta Amazônica, 39:749-758. 